$1-1-1966$

\title{
Characteristics, objectives and motivations of woodland owners in West Virginia
}

Wallance W. Christensen

\author{
A. Edwin Grafton
}

Follow this and additional works at: https://researchrepository.wvu.edu/ wv_agricultural_and_forestry_experiment_station_bulletins

\section{Digital Commons Citation}

Christensen, Wallance W. and Grafton, A. Edwin, "Characteristics, objectives and motivations of woodland owners in West Virginia" (1966). West Virginia Agricultural and Forestry Experiment Station Bulletins. 538.

https://researchrepository.wvu.edu/wv_agricultural_and_forestry_experiment_station_bulletins/492 @ WVU. It has been accepted for inclusion in West Virginia Agricultural and Forestry Experiment Station Bulletins by an authorized administrator of The Research Repository @ WVU. For more information, please contact ian.harmon@mail.wvu.edu. 
West Virginia University Libraries

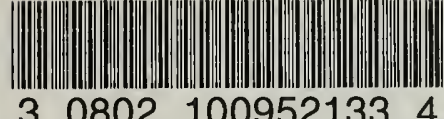
308021009521334 
Digitized by the Internet Archive in 2010 with funding from

Lyrasis Members and Sloan Foundation 
ETIN 538

MBER 1966

(n)

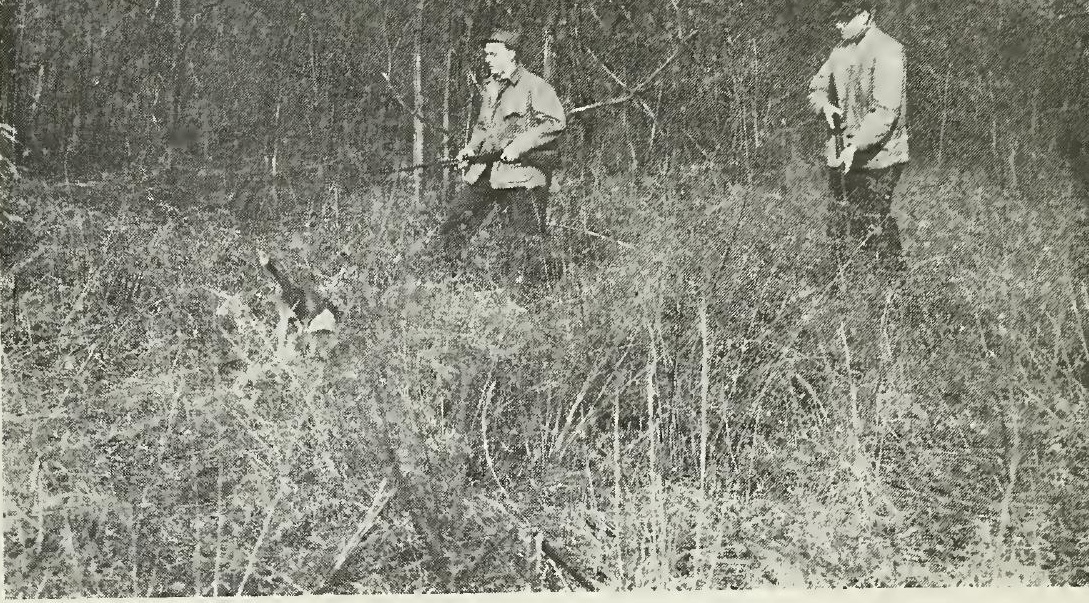

Characteristics, Objectives, and Motivations of

19.

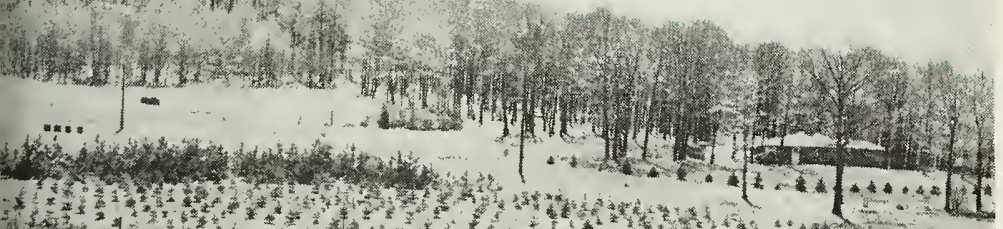

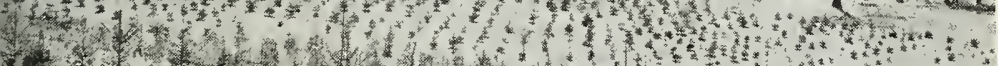

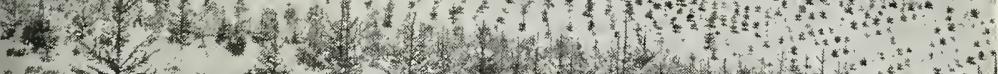

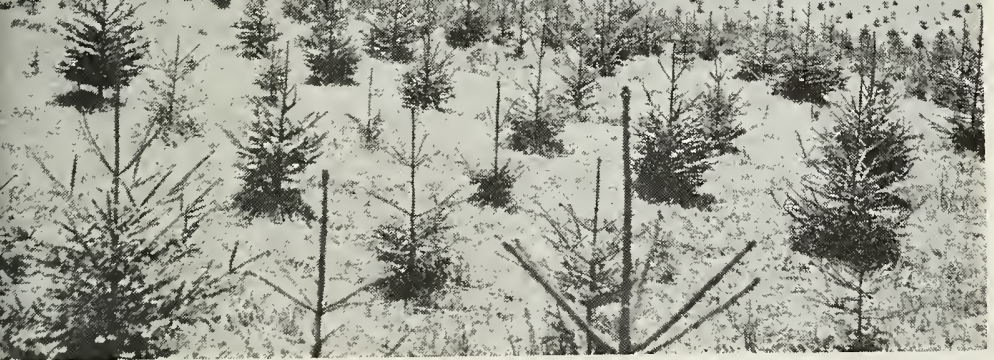

Woodland

Owners

in

West

Virginia
T VIRGINIA VERSITY ICULTURAL ERIMENT TION

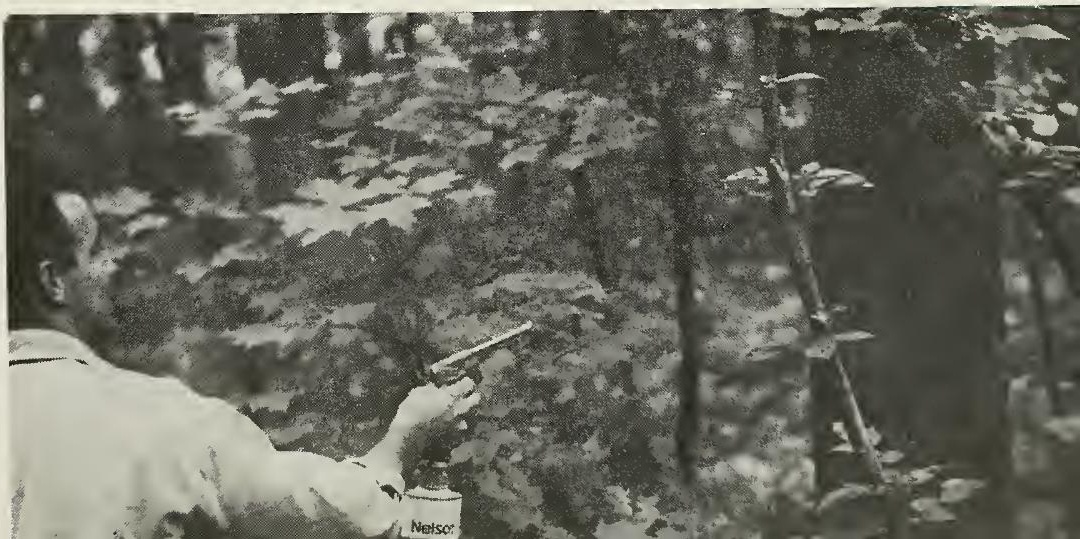





\section{CONTENTS}

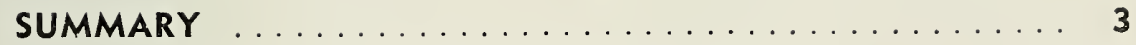

INTRODUCTION $\ldots \ldots \ldots \ldots \ldots \ldots \ldots \ldots \ldots$

RESEARCH PROCEDURE $\ldots \ldots \ldots \ldots \ldots \ldots \ldots \ldots$

FOREST OWNERSHIP PATTERN $\ldots \ldots \ldots \ldots \ldots \ldots \ldots$

OWNERS' OBJECTIVES, TOTAL PROPERTY . . . . . . . . 10

OWNERS' WOODLAND OBJECTIVES ........... 12

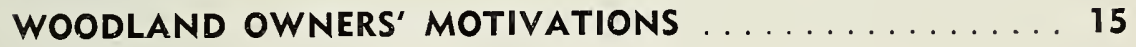

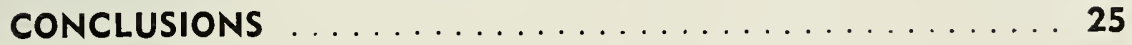




\section{THE AUTHORS}

Wallace W. Christensen is former Associate Forester, now with the U. S. Forest Service; A. Edwin Grafton, former Instructor in Forestry, College of Agriculture and Forestry, is now Lecturer in Forestry, Egerton College, Kenya.

\section{ACKNOWLEDGMENTS}

Front cover pictures and those on pages 12, 14, 15, 17, 20, $21,22,23$, and 24 are used through courtesy of the Soil Conservation Service. Photo on page 25 is by the Cooperative Extension Service.

The authors are grateful to the Claude Worthington Benedum Foundation for the generous grant in support of this study.

West Virginia University

Agricultural Experiment Station

College of Agriculture and Forestry

A. H. Vanlandinghane, Director

MORGantown 


\section{SUMMARY}

West Virginia has long been one of the leading states in production of hardwood lumber and has more standing hardwood sawtimber than any other state. But there are serious problems-problems of low timber quality in a large proportion of the hardwood resource, and forest land productivity considerably below potential. Foresters have long known the practices necessary to improve the situation. What has been less clearly understood is how to get such practices applied, particularly in woodlands under private, non-industrial ownership.

To fill the gap in knowledge, this study was designed to learn more about woodland owners in West Virginia; who they are and why they think and act as they do in relation to their woodlands. Mail questionnaires were sent to a statewide sample of 5,009 woodland owners, and 217 personal interviews were conducted. Data from 1,442 returned mail questionnaires and 217 field interview schedules show that:

1. Two-thirds of West Virginia's commercial forest land is in private, non-industrial ownership-farmers, absentee owners, and rural residents.

2. Three-fourths of the privately owned woodland tracts in the state are in holdings of less than 100 acres.

3. Although the purpose for owning land is generally related to type of ownership, all owner classes have a variety of objectives in mind. Thus it appears that owners view their total holdings (open land plus forest) from a multi-purpose management point of view.

4. As with total property, owners have several objectives relative to their woodland holdings. Wildlife (habitat, and hunting and fishing), direct use of timber products, protective influences of forest cover, and pasturage were the most frequently mentioned ownership objectives. Only one-fourth of the owners reported sale of timber products as an objective.

5. About half the owners not currently selling timber products view their timber as a hedge against future needs, such as putting children through college. But, more typically, timber is held to meet unexpected contingencies that might arise. Coupled with these reasons are others: poor timber stand condition, current prices too low, heirship problems precluding sale, no market demand, and various aesthetic and sentimental reasons.

6. More than four-fifths of the woodland owners do not conduct timber stand improvement work, mainly because they do not have sufficient time. Additionally, many have no interest in such activity, and others are unaware of the necessity for such work. Also a number of owners consider their stands either too poor to justify improvement work 
or the cost too great. Timber stand improvement that is performed, is generally incidental to fuelwood harvesting.

7. About one-fourth of the owners had planted trees on their properties, principally for erosion control, aesthetic or sentimental reasons, Christmas tree business, and for game cover. Lack of interest is the most prevalent reason for not planting.

8. More than 40 per cent of the owners permit livestock grazing in their woodlands. The most frequently mentioned reason for this practice was the prohibitive fencing costs. Some owners consider that livestock will benefit from the shade afforded by forest cover. Others do not have sufficient open pasture area and, interestingly, a few consider woodland grazing as a desirable forestry practice because browsing "keeps underbrush down" and thus reduces fire hazard.

9. Less than one-third of the owners interviewed had participated in any type of government subsidy program-mainly a matter of payments in connection with applying lime and fertilizer for cropland improvement. Forty per cent of those who had not participated indicated that they had not known such programs were available.

10. Lack of interest in selling timber products suggests that perhaps much of the State's sawtimber may not be economically available to wood-using industries in West Virginia. Moreover, it would also appear that "selling" woodland owners on the advantages of conservative forestry practices might well be based on some inducement other than monetary gain. 


\section{Characteristics, Objectives, and Motivations of Woodland Owners in West Virginia}

\section{WALLACE W. CHRISTENSEN and A. EDWIN GRAFTON}

$T$ HROUGHOUT THIS CENTURY West Virginia has steadily been one of the nation's leading producers of hardwood lumber. Although this underscores the State's national importance as a hardwood lumber supplier, it at the same time implies a fairly substantial demand for West Virginia's hardwood sawtimber. Moreover, it seems reasonable to expect an increase in this already heavy demand if current projections of future national requirements for hardwood lumber materialize and if West Virginia continues to maintain its position as one of the leading hardwood lumber-producing states.

Recent findings regarding West Virginia's forest resource suggest that the State is in good position to meet current and potential future demand for hardwood sawtimber. One study, for example, reports that commercial forests now cover three-fourths of the State's total land area and that hardwood sawtimber has increased 65 per cent in the past 12 years. ${ }^{1}$ Another shows that West Virginia now has close to 29 billion board feet of hardwood sawtimber-more hardwood sawtimber than is found in any other state in the nation."

However, these same studies also point out that: (1) almost half of the State's commercial forest land is less than 40 per cent stocked with desirable trees, ${ }^{3}$ (2) about 70 per cent of the hardwood sawtimber volume is of low quality (grade 3 standard-lumber logs or poorer), and (3) slightly over 70 per cent of all commercial forest land is growing less than 50 cubic feet per acre-roughly an average of 150 to 200 board feet per acre per year over the period of a hardwood rotation. Thus there are very real problems of timber quality and forest land productivity. And these problems are essentially related to privately-owned timberlands since 86 per cent of the State's commercial forest land is classified under farm and "miscellaneous private" ownership.

The foregoing problems are not peculiar to West Virginia. These same problems have received considerable attention nationally during

\footnotetext{
1Forest Service, U.S.D.A. The Timber Resources of West Virginia, N.E. Forest Exp. Sta., Resource Bull. NE-2, Upper Darby, Pa., 1964.

${ }^{2}$ Timber Trends in the United States, Forest Resource Report No. 17, G.P.O., Washington, D. C., 1965.

${ }^{3}$ Desirable trees are defined by the Forest Service as: "growing-stock trees having no serious defects in quality limiting present or prospective use, of relatively high vigor, and containing no pathogens that may result in death or serious deterioration before rotation age."
} 
the past 32 years as, for example, in the Copeland Report in 1933, the Forest Service Reappraisal Report in 1946, the President's Materials Policy Commission Report in 1952, the Forest Service's Timber Resource Review in 1958, and the current report on Timber Trends in the United States.

Programs directed toward improvement of forest productivity and timber quality have generally followed two approaches: (1) public regulation of timber management practices on private holdings, and (2) provision of incentives to better management such as more suitable credit and insurance facilities, revision of local or regional tax structure, education, technical assistance, and direct subsidy. Public regulation has not been acceptable, at least on a broad geographic scale. Of the incentives, improvements in insurance and taxation have not been widely applied. Most effort has been directed toward education and technical assistance and, to a lesser degree, direct subsidy.

The combined effect of all efforts, however, has not brought about a significant adoption of more conservative timber management practices by the national aggregate of private, non-industrial woodland owners. Although some advances have been made, as in the "Keep America Green" program, nevertheless each successive national survey has pointed up the continuing problems of low forest productivity and poor timber quality. Thus it would appear that some reorientation in approach is called for.

The major task is essentially one of developing a workable means of getting private, non-industrial woodlands under more conservative management, i.e., the kind of management necessary for improvements in timber quality and productivity. Since the problem is peculiar to one type of ownership, it would seem that the role of research should be in the direction of learning more about woodland owners. Past research, for example, has provided a reasonably clear picture of what various classes of owners do with their woodlands. Yet at the present time surprisingly little is known about why these owners act as they do. In this context, the need for research has been well defined:

"through research we need to know how trees affect people and people
affect trees; not only how trees grow and how men use them, but also why
trees grow as they do and why men use (or abuse) them as they do. It is
easy to assume that because we are dealing with trees, we need scientific
research and information only; but in this particular case we are also dealing
with thousands upon thousands of landowners, whose habits, expectations,
and motivations call for other kinds of research and information."

This study is concerned with the latter part of the foregoing philosophy. The principal aim is to secure a better understanding in West Vir-

Dr. Eldon L. Johnson, President, University of New Hampshire, in an address to the Small Forest Ownerships Conference, Boston, Mass., Sept. 1957. 
ginia regarding the behavior of people in relation to their woodlands, assuming that such knowledge will be of value in the long run process of "selling" more conservative timber management practices on the private, non-industrial holdings. To accomplish this aim, the study was designed to meet the following broad objectives:

1. To determine forest land-use patterns in terms of size of forest holdings, years of ownership, present property usage; and to define certain landowner characteristics such as type of private ownership, age, and educational level.

2. To determine ownership objectives regarding total property as well as the woodlands, and the attitudes and motivations underlying woodland management practices.

\section{RESEARCH PROCEDURE}

Data collection was based on two approaches. First, because of the widely dispersed nature of the population to be sampled and limitations on time and manpower available, mail questionnaires were used to collect information in answer to the first objective described above. Also, the questionnaire used permitted determination of the management objectives of woodland owners (part of the second major objective). This method has received detailed attention elsewhere, with results indicating that the technique represents a sound approach for gathering these specific types of information. ${ }^{5}$

For this phase of the study, a few counties were selected at random from each of West Virginia's "State Economic Areas." The resulting sample included 17 counties whose total rural population amounted to one-third of the State's total. Forest ownership lists were then compiled by randomly selecting names of landowners from landbooks in each county. Questionnaires were mailed to these landowners $(5,009$ individuals). After one follow-up mailing 33 per cent of the owners had returned useable questionnaires.

The second approach involved personal interviews with landowners, since determination of landowner attitudes and motivations cannot be accomplished within any aceptable degree of accuracy by mail survey.

${ }^{5}$ Christensen, W. W. A Methodology for Investigating Forest Owners' Management Objectives, (Ph.D. dissertation), State University College of Forestry at Syracuse University, 1957.

${ }^{6}$ State Economic Areas . . . consist of single counties or groups of counties which have similar economic and social characteristics. The boundaries of these areas have been drawn in such a way that each state is sub-divided into relatively few parts with each part having certain significant characteristics which distinguish it from adjoining areas. In the establishment of State Economic Areas, factors in addition to industrial and commercial activities were taken into account. Demographic, climatic, physiographic and cultural factors, as vell as factors pertaining more directly to the production and exchange of agricultural and non-agricultural goods, were considered. The net result then is a set of areas... which arre relatively homogeneous with respect to a large number of characteristics. U. S. Census of Agriculture-1950; Virginia and West Virginia, Vol. I, part 15. 
In this case, the sampling universe was obtained from the U. S. Forest Service. The universe was stratified by timber volume and size of woodland holdings and the interview sample randomly drawn from these strata. In all, 217 woodland owners across the State were interviewed.

\section{FOREST OWNERSHIP PATTERN}

About one-tenth of West Virginia's commercial forest land is publicly owned; the remainder is largely under private, non-industrial ownership (Figure 1). Some difference exists between the ownership pattern shown in Figure 1 and that of the recent Forest Service survey report. The difference, principally in the farm ownership sector, arises because of differences in definition. In the present study, for example, a "farm"
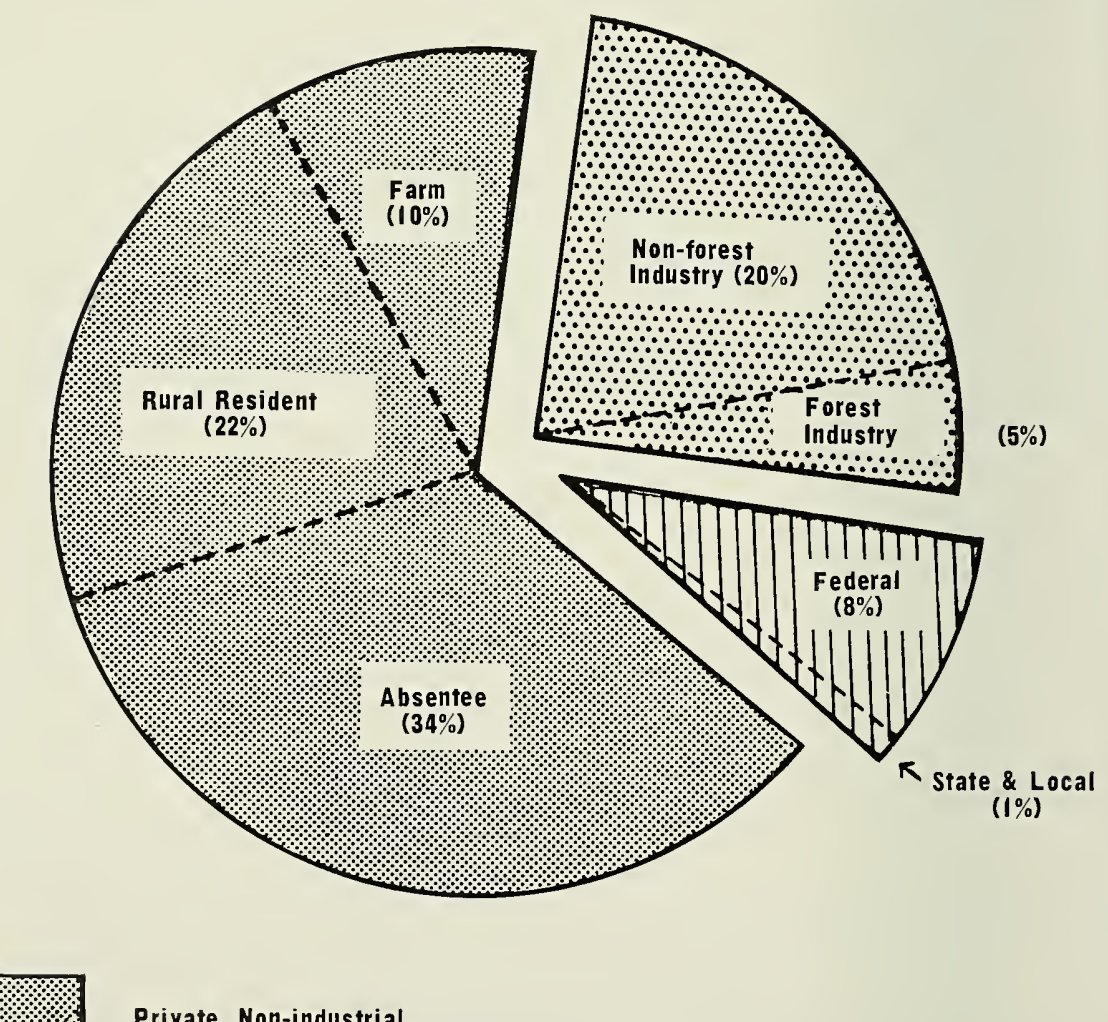

Private, Non-industrial

Private, Industrial

Public

Figure 1. Ownership of commercial forest land in West Virginia (In per cent of total forest acreage). 


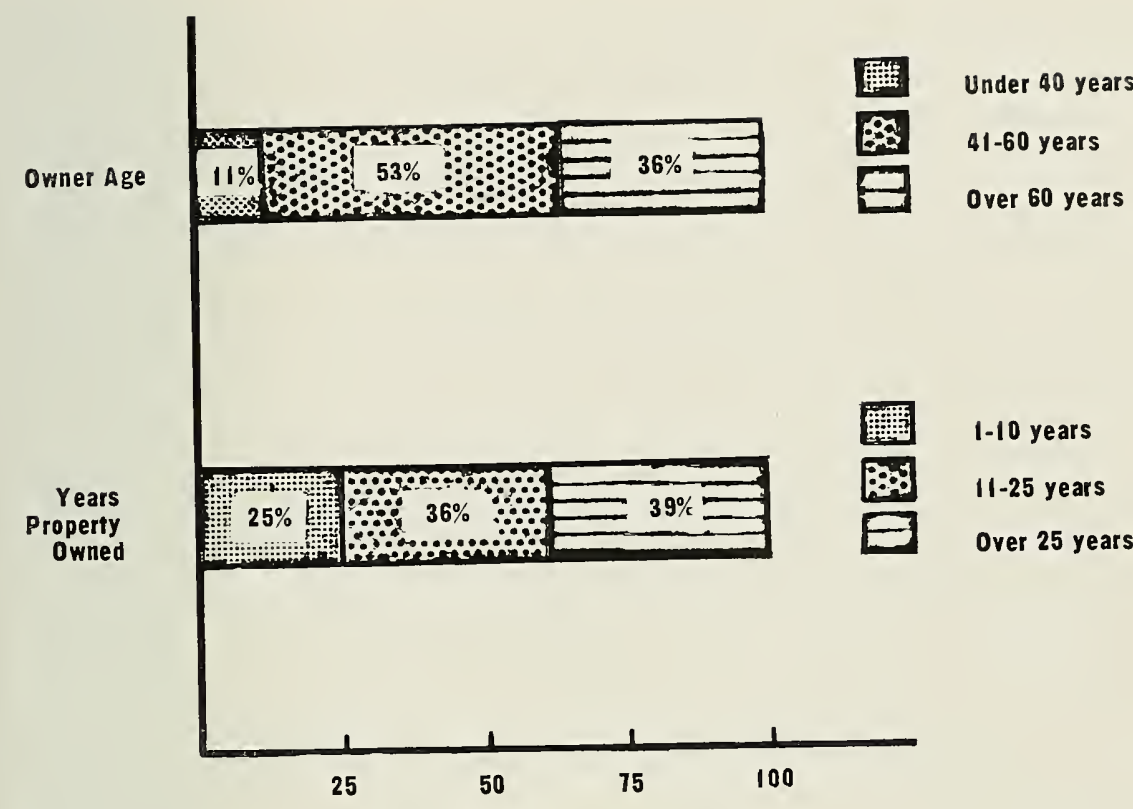

Per cent of woodland owners

Figure 2. Forest land ownership by owner age-class and tenure.

was considered to be a place on which farming activity provided the owner with his main source of livelihood-a full time farm. By contrast, a "farm" in the Forest Service survey report was a place ". . . of 10 or more acres from which the sale of agricultural products totaled $\$ 50$ or more annually, or a place of less than 10 acres from which the sale of agricultural products totaled $\$ 250$ or more during the previous year." Under this latter definition a landowner could be an individual whose main source of income from non-farming activity as, e.g., a job in an industrial plant in a nearby urban area. If this individual sold at least $\$ 50$ worth of agricultural products during the year, he would be classified as a "farmer" in the Forest Service Survey, as a "rural resident" in the present study.

Absentee owners, who hold one-third of West Virginia's forest land, live relatively close to their forest properties. For example, two-thirds of the properties are within 25 miles of the owner's permanent residence, only 14 per cent are over 100 miles. This proximity probably accounts in

7Forest Service, U.S.D.A. Timber Trends in the United States, Forest Resource Report 17, G.P.O., Washington, D. C., 1965. 
large measure for the frequency of owner visits to their absentee woodlands-two-thirds of the absentee owner respondents indicated that they visited their forest properties four or more times a year.

Taken as a group, private woodland owners in West Virginia are concentrated in the older age brackets which, in turn, may explain the fact that almost 40 per cent of the owners have held their forest land for more than 25 years (Figure 2). In terms of educational background, onetenth of the private woodland owners have attended college; the remainder are evenly divided between those who have attended high school and those whose education did not progress beyond the grade school level.

Small woodland tracts predominate in the State, with three-fourths of all private ownerships in holdings of less than 100 acres and one-fifth in properties ranging from 100 to 1,000 acres. Some consolidation of small ownership into large blocks of forest land is taking place in various parts of West Virginia, carried on mainly by wood industries. However, the scale of such programs at the present time is relatively small.

\section{OWNERS' OBJECTIVES, TOTAL PROPERTY}

The reasons for owning land would seemingly be self evident since farmers, for example, presumably own property to secure an income from it, rural residents for the housing on it, and so on. However, this study assumed that landowners have several objectives for holding property. Thus one of the aims was to test this assumption and, if the assumtion proved valid, to describe the "bundle of objectives" of the various types of landowners.

As shown in Table 1, owner objectives are related to type of ownership; farmers, absentee owners, and industrial owners are largely concerned with income from their holdings, rural residents with housing.

\section{TABLE 1}

\section{Purpose of Ownership by Type of Owner}

\begin{tabular}{|c|c|c|c|c|c|c|}
\hline Purpose of & Ownership & Farmer & $\begin{array}{c}\text { Rural } \\
\text { Resident }\end{array}$ & $\begin{array}{l}\text { Absentee } \\
\text { Owner }\end{array}$ & $\begin{array}{c}\text { Wood } \\
\text { Industry }\end{array}$ & $\begin{array}{c}\text { Other } \\
\text { Industry }\end{array}$ \\
\hline & & \multicolumn{5}{|c|}{ Per Cent ${ }^{* *}$} \\
\hline For the house & & 45 & 78 & & & 3 \\
\hline For recreation & & 13 & 29 & 32 & 25 & 3 \\
\hline Earn income. & & 99 & 55 & 45 & 87 & 71 \\
\hline Sell property & & 5 & 10 & 25 & 12 & 6 \\
\hline Speculation and & future income & 1 & 4 & 15 & 25 & 39 \\
\hline Miscellaneous & $\ldots \ldots \ldots \ldots$ & 1 & 6 & 9 & 12 & 3 \\
\hline No purpose & & & 3 & 9 & & 3 \\
\hline
\end{tabular}

* Includes satisfaction of ownership, freedom from urban areas, etc.
* Percentages do not total 100 because any individual respondent could list more than one objective. 
But the data also show that a variety of objectives exist for the various types of owners.

In addition to earning income, about 1 of every 7 farmers views recreational use of their property as an objective and almost half of them consider housing an objective. Although most of the rural residents consider housing a purpose for owning property, about 1 in every 3 also cites recreation, and more than half of them list income-almost entirely part-time income and mainly a matter of raising a few head of young stock and some garden crops for home consumption.

The income objective of absentee owners is predominantly a parttime income, largely from farming but also from mining, logging, and property rentals. One in every 3 absentee owners uses the property for recreational purposes and around 1 in every 10 reports intangible objectives such as satisfaction derived from owning a piece of rural property, opportunity which the property provides as an occasional escape from pressures of urban life, and the like.

Although most of the wood industry owners are interested in fulltime income aspects of their properties now or in the future, 1 in every 4 of them also reported recreation as an objective. This, perhaps, signifies a trend toward multiple-use of industrially owned forest land under the impact of rapidly increasing demand for forest recreation. Other types of industrial owners appear to be interested primarily in present and future income from the land, either through earned income from resources on or in the land or through investment.

For owners listing income as an objective, farming was reported most frequently in non-industrial ownerships, mining and logging most frequently by industrial owners (Table 2). Interestingly, a surprising proportion of wood industry owners listed land rental, with or without the house, as a form of income.

\section{TABLE 2}

\section{Source of Full-Time or Part-Time Income by Type of Ownerships}

\begin{tabular}{|c|c|c|c|c|c|c|}
\hline Source of Income & Farmer & $\begin{array}{c}\text { Rural } \\
\text { Resident }\end{array}$ & $\begin{array}{c}\text { Absentee } \\
\text { Owner }\end{array}$ & $\begin{array}{l}\text { Wood } \\
\text { Industry }\end{array}$ & $\begin{array}{l}\text { Other } \\
\text { Industry }\end{array}$ & $\begin{array}{c}\text { All } \\
\text { Owners }\end{array}$ \\
\hline & $P e$ & r Cent of & $f$ Owners & Reportin & g Income & 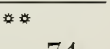 \\
\hline Farming & 99 & 80 & 47 & & 9 & 74 \\
\hline Mini & 1 & 4 & 13 & 57 & 65 & 8 \\
\hline & 7 & 12 & 19 & 80 & 39 & 14 \\
\hline Rental of house and land & 4 & 9 & 20 & 43 & 9 & 11 \\
\hline Rental of house only ... & 3 & 6 & 12 & & & 6 \\
\hline Rental of land only. & 5 & 10 & 20 & 29 & 13 & 12 \\
\hline Business $\ldots \ldots \ldots$ & 1 & 4 & 7 & $\ldots$ & 13 & 4 \\
\hline Miscellaneous ${ }^{*}$ & 1 & 1 & 3 & & & 2 \\
\hline
\end{tabular}

Includes recreation development, share-farming, and gardening. "Percentages do
by any one respondent. 


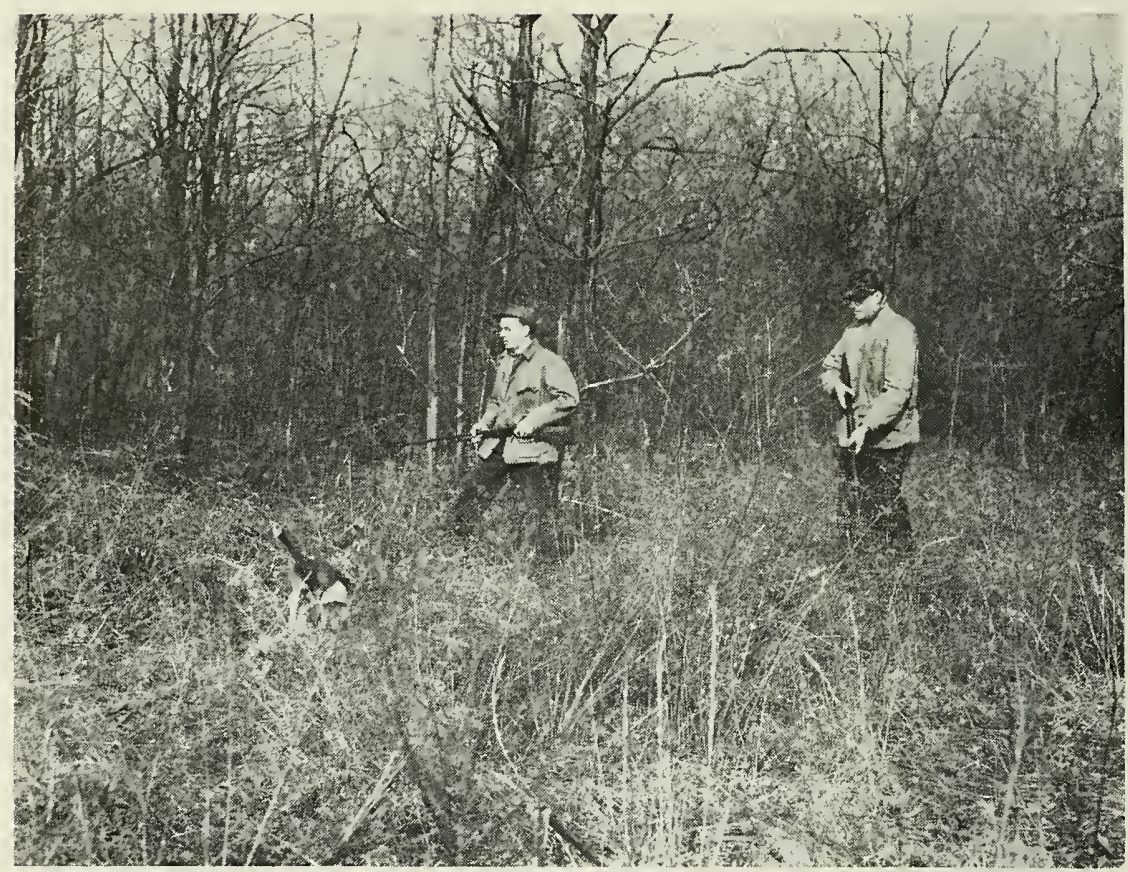

Wildlife is the most common woodland objective of West Virginia landowners.

\section{OWNERS' WOODLAND OBJECTIVES}

Determination of owners' woodland objectives rested on the same assumption as that underlying total property objectives, i.e., that owners presumably would have several objectives in mind. In view of this, respondents were requested to check as many of the listed woodland objectives as applied in their individual cases. No attempt was made to determine the relative importance of various objectives for each owner, because the findings of a similar study in another state ${ }^{\mathrm{s}}$ revealed that such a process was difficult for many respondents.

For all owner types combined, wildlife (game habitat, hunting, fishing) was the most frequently mentioned woodland objective (Figure 3 ). Direct use of timber products, livestock pasturage, and the protective aspects of forest cover also appeared as woodland objectives for about 1 out of every 2 owners. Only one-fourth of the owners considered sale of timber products an objective.

As might be expected, the pattern of woodland objectives varied among ownership types. Direct use of timber products was cited most

\footnotetext{
'Christensen, W. W. A Methodology for Investigating Forest Owners' Management Objectives, (Ph.D. dissertation), State University College of Forestry at Syracuse University, 1957.
} 
Per cent

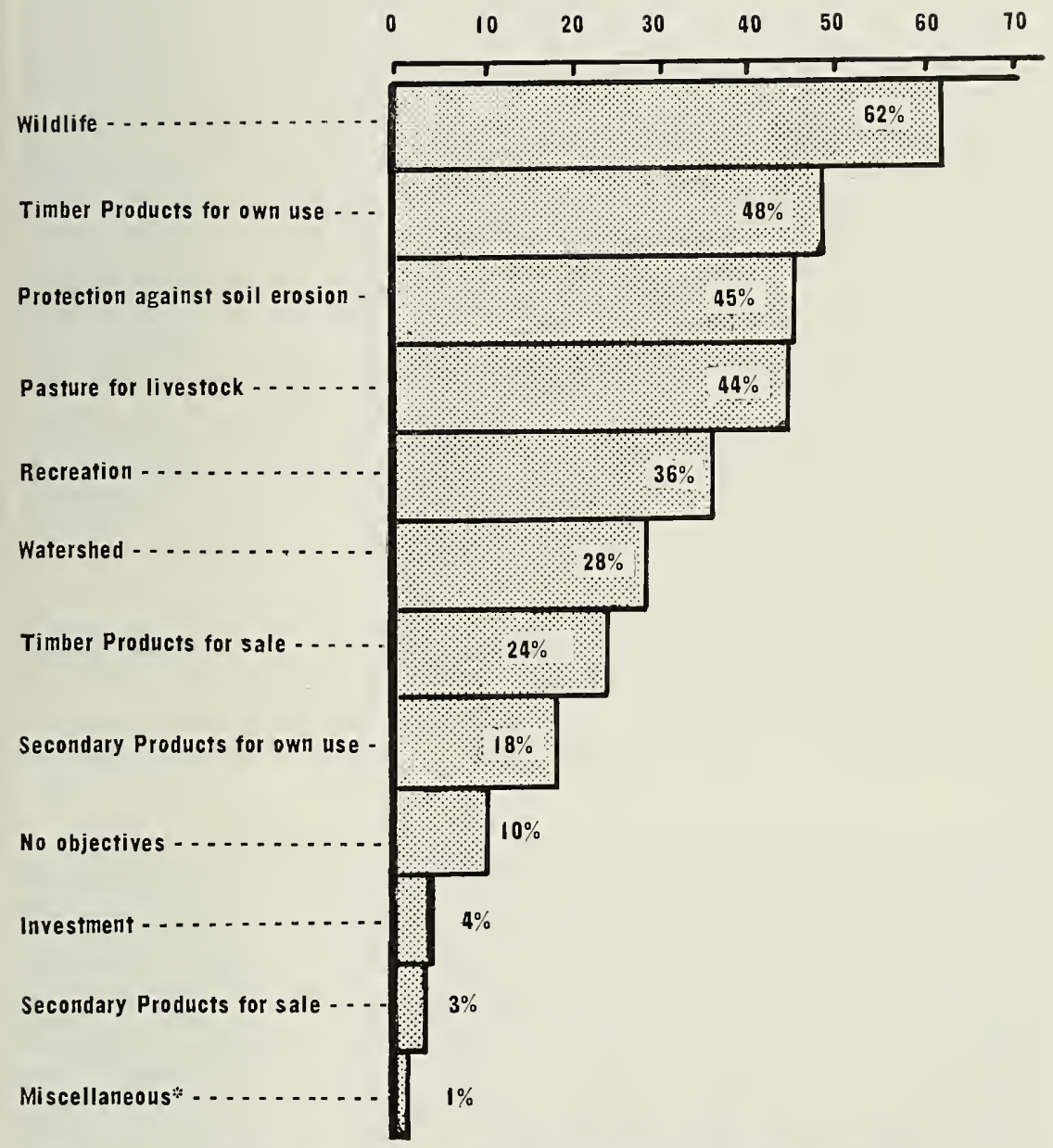

Figure 3. Reported woodland objectives (in per cent of all respondents).

frequently by farmers and wood industries, wildlife by rural residents and absentee owners, and sale of timber products by the non-wood industries (Table 3). However, all owner types indicated other woodland objectives in sufficient frequencies to adequately substantiate the "bundle of objectives" concept assumed in the design of this study. Thus, although more than three-fourths of the farmers considered home use of timber products an objective, nearly two-thirds also viewed wildlife and pasturage as objectives, one-half listed protection against soil erosion, and one-third reported watershed. As Table 3 shows, similar patterns-in 
TABLE 3

Woodland Objectives by Type of Ownership

\begin{tabular}{|c|c|c|c|c|c|}
\hline Woodland Objectives & Farmer & $\begin{array}{c}\text { Rural } \\
\text { Resident }\end{array}$ & $\begin{array}{l}\text { Absentee } \\
\text { Owner }\end{array}$ & $\begin{array}{l}\text { Wood } \\
\text { Industry }\end{array}$ & $\begin{array}{l}\text { Other } \\
\text { Industry }\end{array}$ \\
\hline & \multicolumn{5}{|c|}{ Per Cent* } \\
\hline Wildlife $\ldots \ldots \ldots \ldots \ldots$ & 63 & 67 & 55 & 50 & 42 \\
\hline Timber products for own use & 77 & 52 & 29 & 88 & 42 \\
\hline Protection against soil erosion & 50 & 51 & 34 & 62 & 19 \\
\hline Pasture for livestock ........ & 63 & 48 & 30 & 25 & 10 \\
\hline Recreation $\ldots . . .$. & 23 & 38 & 39 & 62 & 26 \\
\hline Watershed ............ & 33 & 32 & 19 & 38 & 13 \\
\hline Timber products for sale ..... & 30 & 21 & 23 & 62 & 48 \\
\hline Secondary products for own use & 26 & 20 & 11 & 12 & \\
\hline No objectives $\ldots \ldots \ldots \ldots \ldots \ldots$ & 5 & 6 & 16 & & 4 \\
\hline Investment $\ldots \ldots \ldots \ldots$ & 2 & 2 & 6 & 12 & 19 \\
\hline Secondary products for sale & 1 & 1 & 2 & & 2 \\
\hline Miscellaneous ${ }^{*} \quad \ldots \ldots \ldots \ldots$ & 4 & 3 & 2 & 12 & \\
\hline
\end{tabular}

- Percentages do not total 100 because any one owner could check more than one objective.

* Includes aesthetic and sentimental values, shade, and rental.

terms of multiplicity of objectives-occurred also for the other owner types.

Interestingly, relatively small proportions of the private, non-industrial woodland owners (who, in the aggregate, hold two-thirds of the State's commercial forest land) considered sale of timber products as an objective. Some ramifications attending this finding will be discussed later.

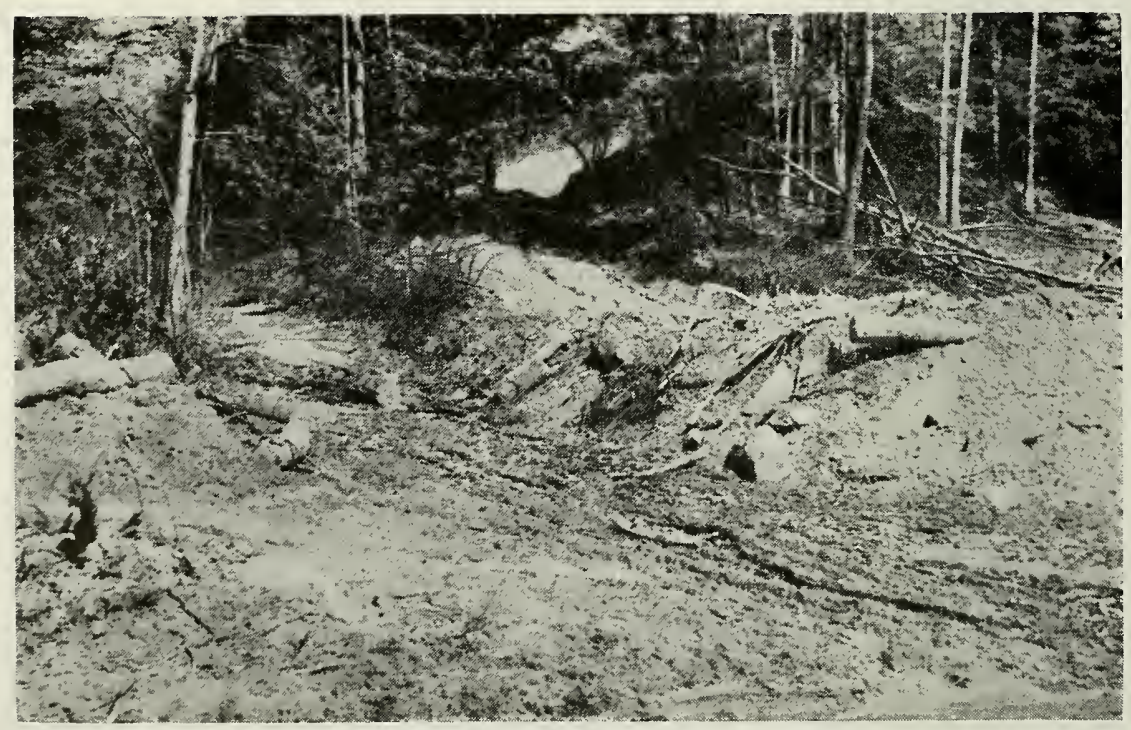

This is erosion caused by improper logging operations. Nearly half of the State's landowners are holding their woodlands for protection against soil erosion. 


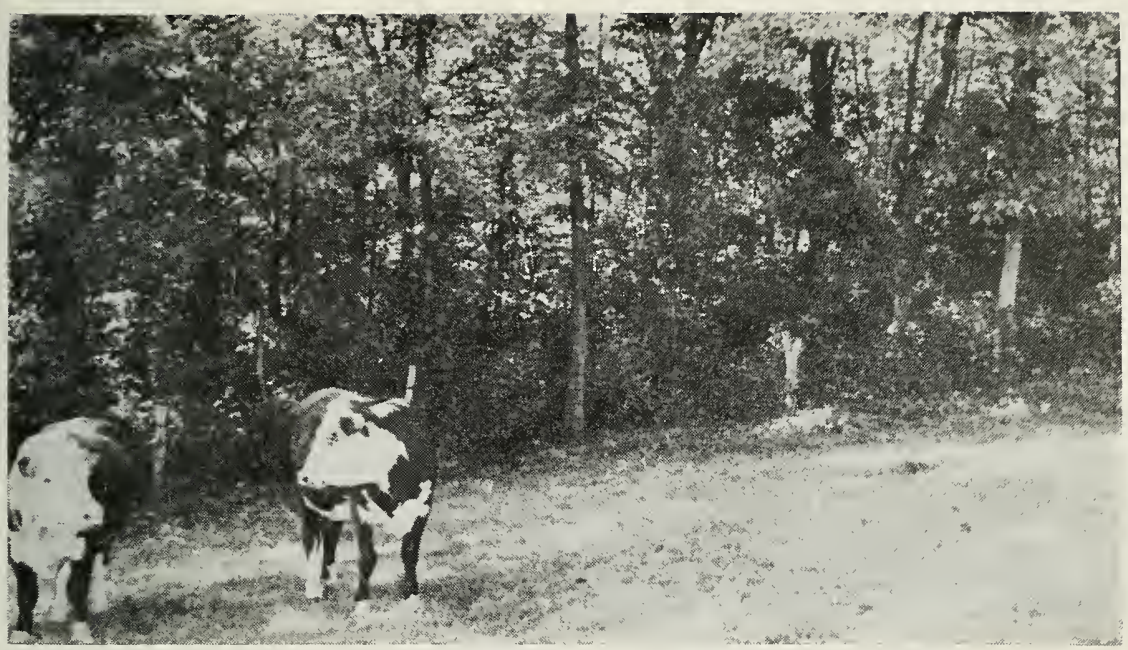

Note the fence that protects the woodland from grazing.

Also of interest is the apparent multi-purpose management of forest land under industry ownership. For example, although nearly 80 per cent of these owners cited direct use of timber products as an objective, presumably as raw materials in their operations, almost two-thirds mentioned recreation and the soil stabilizing influence of forest cover as objectives and half of them listed the wildlife objective.

\section{WOODLAND OWNERS' MOTIVATIONS}

As indicated earlier, very little is known concerning the reasons underlying the behavior of people relative to their woodlands. Why, for example, do some owners sell their timber, carry out timber stand improvement, and plant trees while others do not? Why do some allow livestock to forage in the woodland while others fence the livestock out? Why do some participate in ACP or Soil Bank benefit programs while others do not? One of the basic assumptions of this study was that answers to such questions are necessary for a better understanding of present land use patterns. Effective planning might then result for possible future programs aimed at more conservative woodland management.

Timber products aspects-Perhaps one of the most significant findings concerning woodland objectives is the relatively minor role of timber products sales, i.e., minor in the sense that only one-fourth of the owners consider this an objective of ownership. Why is it that 3 out of every 4 woodland owners have no commercial objectives in mind?

Although a rather wide variety of reasons was given, the one most frequently mentioned (46 per cent of owners not selling timber) was 


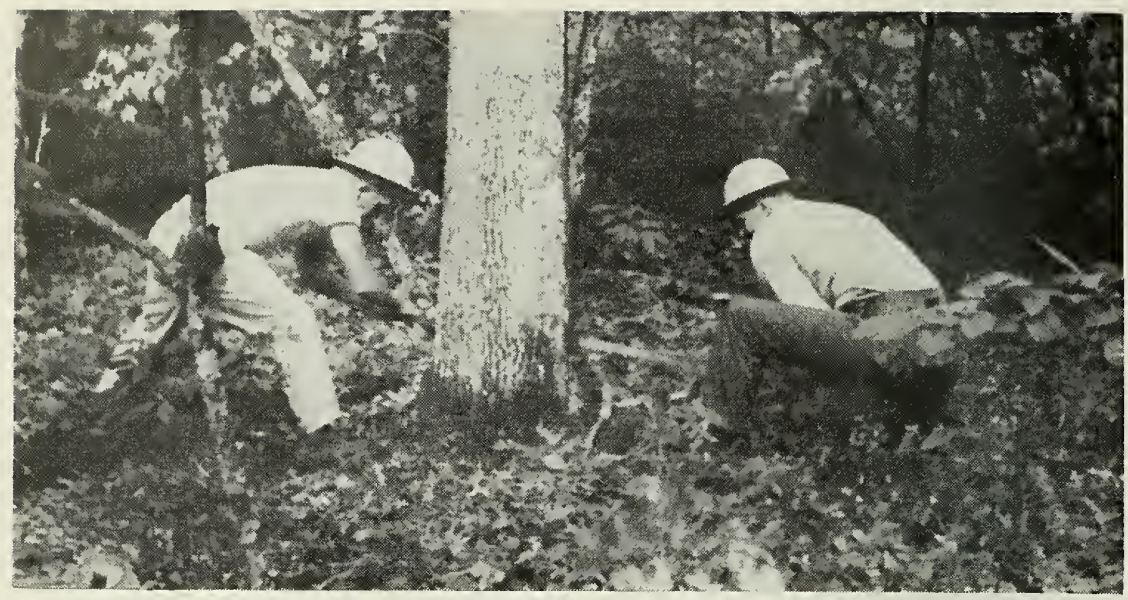

About a fourth of the forest landowners sell timber products, primarily to meet current expenses.

that the timber was being held in reserve for future contingencies. In some cases such contingencies were expected, such as costs of putting children through college. However, the majority of owners reported that timber was being held to meet unexpected contingencies. Most common of these were: (1) having timber available as a source of raw material to rebuild any structures that might be destroyed by fire, and (2) having timber available for sale in the event that emergency money needs might arise as, e.g., medical costs attending severe injury or prolonged illness in the family.

Approximately 1 in every 3 owners explained the lack of a commercial objective in terms of poor timber stand conditions-that past cutting had so depleted the stand that no merchantable timber was available for sale. One in every 5 owners felt that current prices were too low.

Other reasons given (ranging from 2 per cent to 8 per cent of all owners not selling timber) were that the owner could not do his own logging because of physical inabilities and the high cost of his hired labor, that there seemed to be no market demand for stumpage, that heirship problems prevented sale, and that for various aesthetic or sentimental reasons the owner wanted no cutting to take place in his woodland.

Very rarely did an owner cite only one of the foregoing reasons in explaining the lack of a commercial objective. The general pattern was one of various combinations of reasons for not selling timber products.

Of the owners who reported selling their timber, almost threefourths (72 per cent) stated they had done so to meet current expenses 
such as tax payments, working capital, or to meet emergency money needs. Other reasons, ranging from 2 per cent to 15 per cent of owners selling timber, were: (1) owners needed more pasture or cropland, (2) owners felt that timber was mature and needed cutting, and (3) owners believed the current timber products prices were at a high level and, accordingly, that advantage should be taken of this price situation.

Timber stand improvement-A large majority of the woodland owners ( 82 per cent) reported that they had not carried out any form of stand improvement in their woodlands. About three-fourths of these owners listed a lack of sufficient time as the reason for no stand improvement work; one-fifth indicated lack of interest as a cause. Other less frequently mentioned reasons were physical inability of the owner to perform such work, unawareness that such work was necessary, stand stocking too poor to justify such a program, expense considered excessive, heirship problems, lack of markets for products attending improvement work, and plans for impending sale of property.

Of those owners who had performed stand improvement, half stated that the improvement work was incidental to fuelwood harvesting. In these cases, owners harvested only low quality trees for firewood.

Approximately 45 per cent of the owners performing timber stand improvement reported they considered such activity in their woodlands to be a good investment. Since a number of reasons could be given by any one owner, it was not possible to discern from the data the real sig-

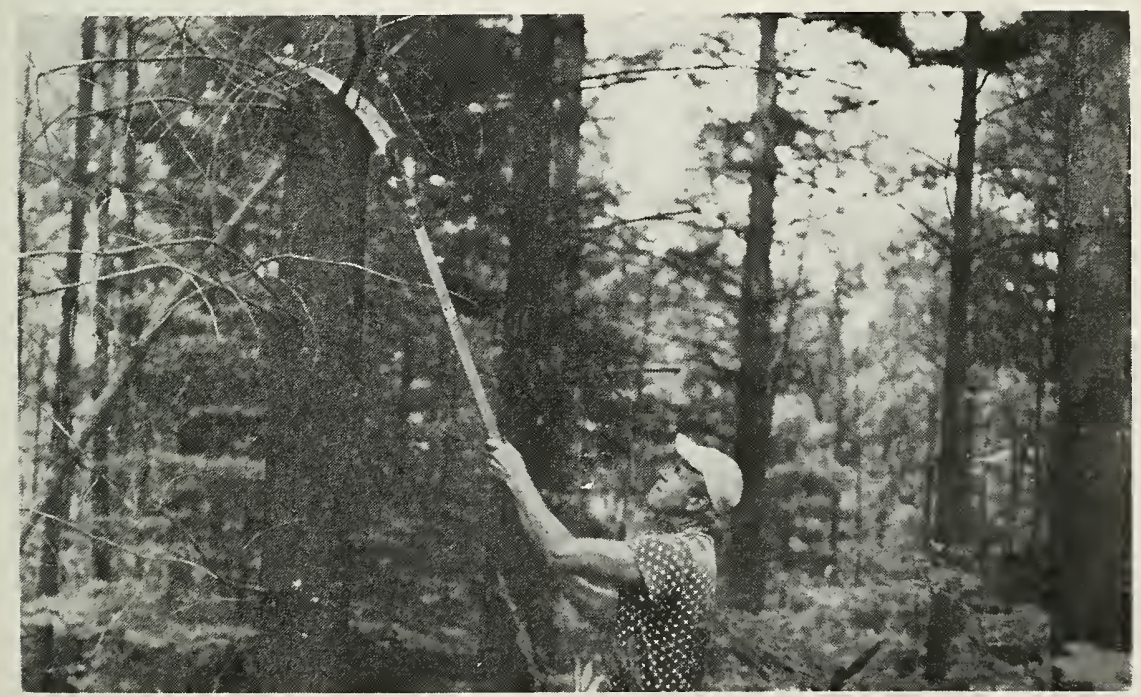

Pruning the best trees in pine plantations results in more high-grade lumber per tree. 


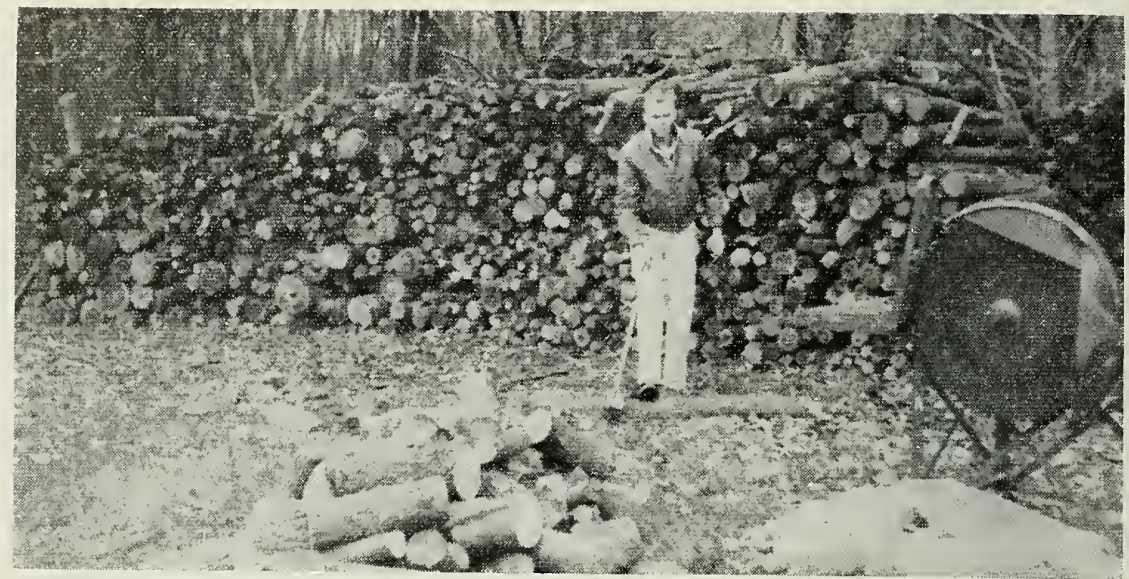

The primary motivation for performing timber stand improvement in the small woodlot is to obtain firewood for home use.

nificance of the investment motive. Unquestionably, a number of owners reporting this reason was also harvesting fuelwood. If these individuals were to convert their home heating system to non-wood fuel types, thus eliminating the need for firewood, would they continue timber stand improvement? And if they did not continue improvement work, what effect would this have on the proportion of owners citing "good investment" as a reason for carrying out stand improvement programs?

Other reasons given, ranging from 2 to 15 per cent of those conducting improvement work, were: planning for recreational use, enjoyment in just "puttering around" in the woods, and to enhance the aesthetic values of the property.

Tree planting-Of all landowners interviewed, about 25 per cent reported that they had planted trees on their properties. The reasons most commonly given for planting were erosion control, aesthetic or sentimental, Christmas tree business, and game cover (Table 4).

Most of the planting was done by rural residents who, as a group, accounted for nearly 60 per cent of all trees planted. Absentee owners planted about one-fifth of all trees, farmers one-tenth, and non-wood industry owners one-tenth. Planting on non-wood industry holdings was largely a matter of strip-mine reclamation work by coal companies. Wood industry ownerships represented less than 1 per cent of all trees planted.

Of the woodland owners who had not planted trees ( 75 per cent of all owners), 3 out of every 5 indicated lack of interest as the reason for not planting. A little over one-fourth reported that they had not planted trees because they had no idle open land available for such a program. 


\section{Owners' Reasons for Tree Planting}

Reasons for Planting Trees

Percentage of Landowners Planting*

\begin{tabular}{|c|c|}
\hline Erosion control $\ldots \ldots \ldots \ldots \ldots$ & 26 \\
\hline Aesthetic or sentimental reasons & 26 \\
\hline Christmas tree business ....... & 25 \\
\hline Cover for game $\ldots \ldots \ldots$ & 21 \\
\hline Eventual timber crop & 19 \\
\hline Watershed purposes ........ & 17 \\
\hline Put idle land to productive use & 16 \\
\hline Windbreak $\ldots \ldots \ldots \ldots \ldots$ & 9 \\
\hline $4-\mathrm{H}$ or Scouting projects ... & 6 \\
\hline Fruit trees $\ldots \ldots \ldots \ldots$ & 6 \\
\hline Fence posts & 4 \\
\hline
\end{tabular}

- Percentages do not total 100 because more than one reason could be given by an owner.

Other, less frequently mentioned, reasons were: lack of knowledge about tree planting, forested area already adequate, planting considered too expensive, and heirship problems.

Perhaps the major reason for lack of planting on wood industry holdings is that the State's lumber industry is based principally on hardwood timber and, with the possible exception of yellow-poplar, hardwood plantings have not been very successful. Moreover, natural regeneration following logging has generally provided for adequate stocking in most harvested stands. Additionally, open land that could be economically planted is relatively scarce in West Virginia and, where open land exists, the terrain is not generally adaptable to the use of planting machines.

Woodland pasturage-For many years foresters have been concerned with the prevalence of domestic livestock grazing in woodlands. As a result, considerable effort has been expended in attempts to educate woodland owners regarding the destructive influences on forest growth attending unrestricted woodland grazing. In view of these efforts, why is it that 44 per cent of the forest owners in West Virginia allow domestic livestock grazing in their woodlands?

Surprisingly, most owners report reasons other than the food value of woodland forage. Indeed, most owners are well aware that woodland forage plants are of low nutritive value. The reason most often given (59 per cent of owners allowing woodland grazing) was that the cost of fencing was too high-that they could not afford this additional expense unless it was accompanied by some additional income. Although cessation of grazing would produce a beneficial effect on forest growth, this generally is not considered as an "additional income" item principally because of the amount of time involved before any tangible benefit would be realized. 


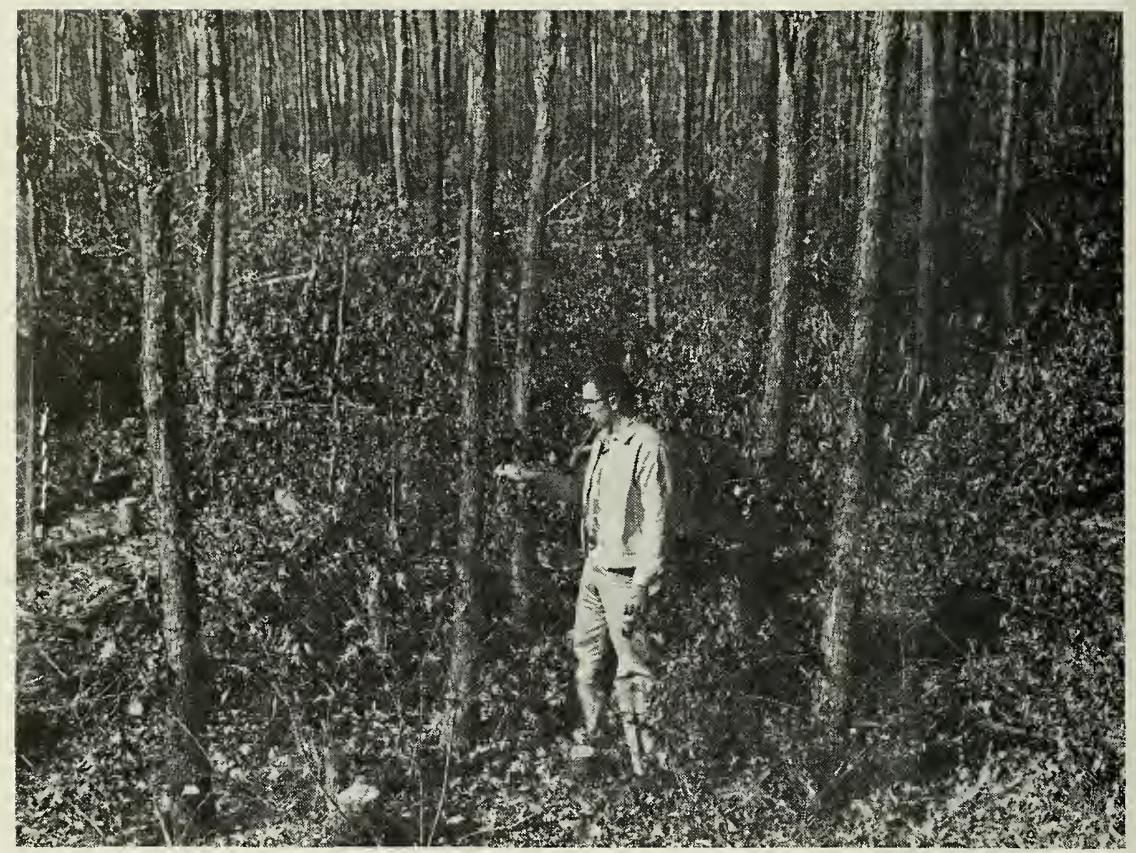

Timber stand improvement (T.S.I.) increases the quality and value of woodland holdings; however, less than a fifth of the landowners have applied T. S. I. practices.

Various other reasons were given also. Some owners, for example, believe that during the summer their livestock will benefit from the shade afforded by forest cover. Others reported that open pasture area was insufficient, and a few considered woodland browse to be good forage. Interestingly, some owners believed that allowing livestock to graze their woodlands constituted a desirable forestry practice because livestock browsing "kept the underbrush down" and thus contributed to a reduction in fire hazard.

Of those owners who reported no pasturing in the woodland area, over half ( 55 per cent) did not own livestock. More than one-third reported that they had sufficient pasture land and could see no point in utilizing the wooded area for forage. Others said that grazing was too damaging to the woodland from the standpoint of wood growth, water control, wildlife habitat, and, in some instances, aesthetic values.

Landowner participation in government subsidy programs-Of all woodland owners interviewed, less than one-third ( 31 per cent) reported participation in subsidy programs such as the Agricultural Conservation Program or the Soil Bank Program. Most of the owners who had received benefit payments were farmers who obtained this type of finan- 


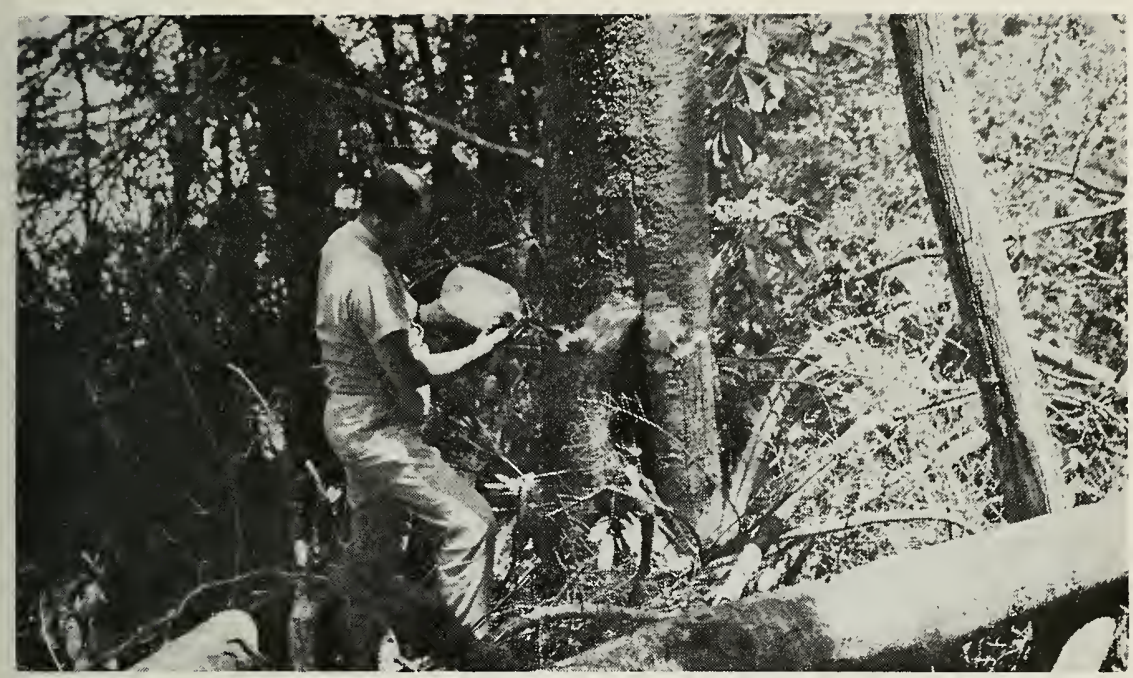

Chemicals can be used to rid woodlands of undesirable trees. Nearly three-fourths of the landowners, however, reported lack of time to apply such practices.

cial assistance in connection with purchase of lime and fertilizer for cropland improvement (Table 5). Only 1 per cent of the woodland owners reported receipt of subsidy for timber stand improvement; 3 per cent for tree planting.

Owners who had received subsidy payments were questioned regarding their reaction to government benefit programs. About half of them reported that they were pleased with the program and could not

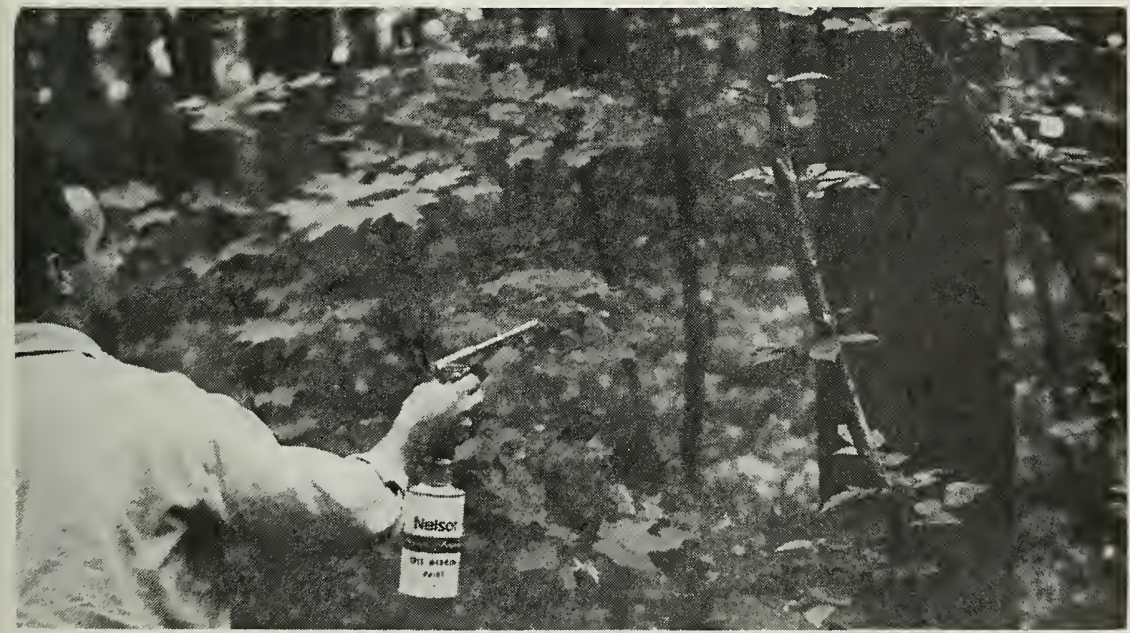

Only 7 per cent of the landowners marked their timber prior to harvesting. 
TABLE 5

Government Subsidy Payments by Purpose and Type of Owner

\begin{tabular}{|c|c|c|c|c|}
\hline $\begin{array}{l}\text { Purpose of } \\
\text { Payments }\end{array}$ & Farmer & $\begin{array}{l}\text { Rural } \\
\text { Resident }\end{array}$ & $\begin{array}{c}\text { Absentee } \\
\text { Owner }\end{array}$ & $\begin{array}{c}\text { All } \\
\text { Owners }\end{array}$ \\
\hline & \multicolumn{4}{|c|}{ Per Cent } \\
\hline No participation & 50 & 76 & 69 & 69 \\
\hline Tree planting .. & 2 & 2 & 4 & 3 \\
\hline 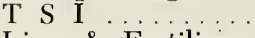 & 5 & 1 & & 1 \\
\hline Lime \& Fertilizer & 43 & 18 & 18 & 23 \\
\hline Miscellaneous $^{*} \ldots$ & 2 & 5 & 10 & 6 \\
\hline
\end{tabular}

oncludes farm pond construction and "Soil Bank" payments.

have undertaken the particular land practice involved without such financial assistance. Three in every 10 indicated indifference to the subsidy received, stating that they would have undertaken the land practices without assistance. Fifteen per cent were pleased with the payment but it was not possible to ascertain if these owners would have undertaken the land practices mentioned without initial assurance of financial assistance. Only 8 per cent of those receiving subsidy payments indicated disappointment in the program.

Since more than two-thirds of the landowners had not participated in the Agricultural Conservation or Soil Bank program, an attempt was made to determine reasons for lack of participation. The major reason was lack of knowledge regarding such programs-about four-tenths of the landowners reported that they had not known such programs were

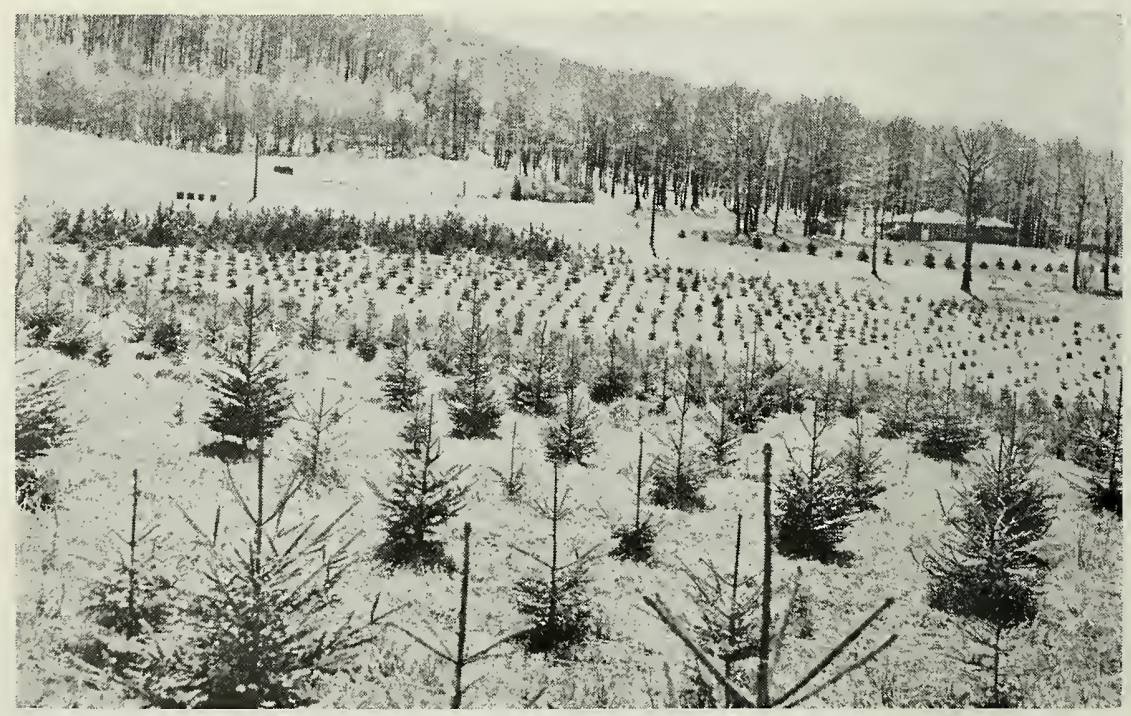

About a fourth of the landowners in West Virginia plant trees primarily for erosion control, aesthetic reasons, and Christmas trees. 


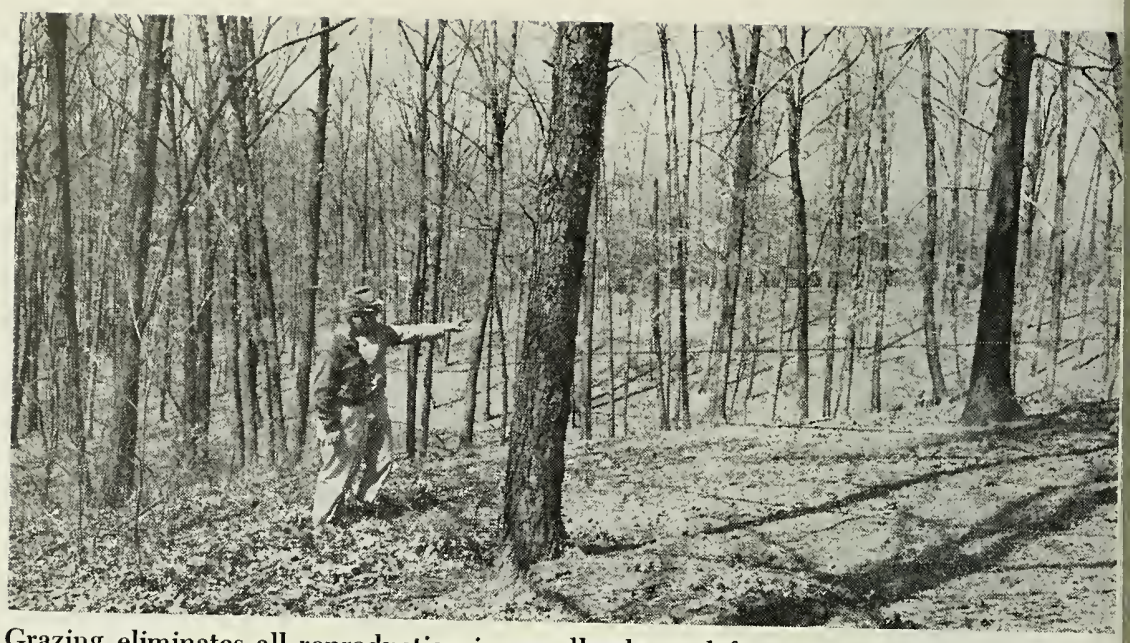

Grazing eliminates all reproduction in woodlands used for pasture. Note the absence of leaf cover and young reproduction in the grazed woodland in the background.

Owner use of professional forestry service-More than two-thirds of the owners interviewed had never contacted professional foresters and about 60 per cent were not aware that forestry services were available from various public agencies. Of those owners who knew that such services were available, 95 per cent reported that they had not utilized the service-mainly because they "had never got around to it," although 1 in 5 felt that they had no need for such service and 1 in 10 did not want to be bothered with the "red tape" involved or indicated complete lack of interest in forestry.

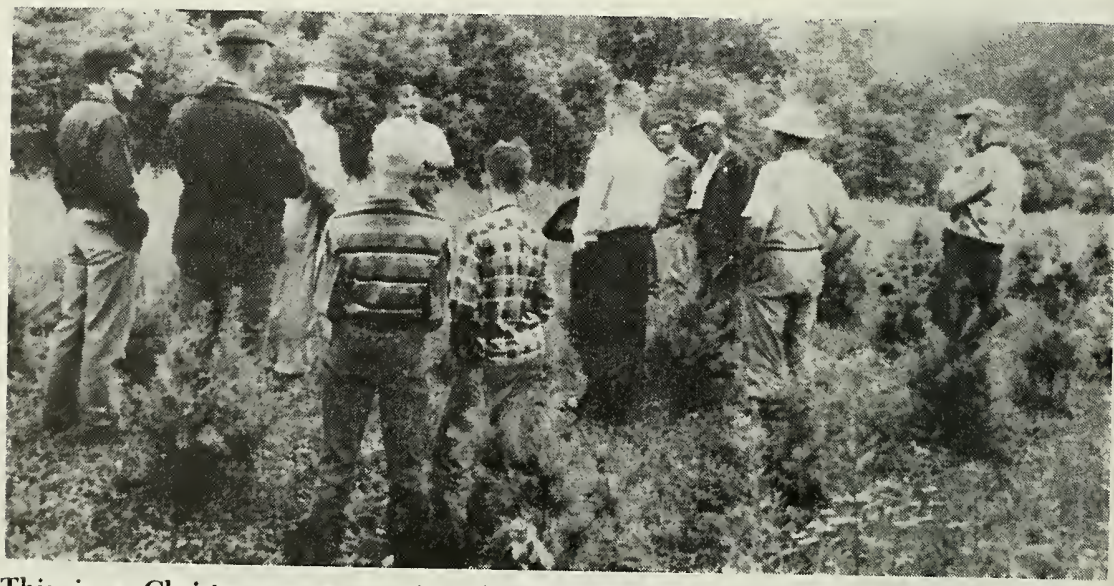

This is a Christmas tree pruning demonstration sponsored by the West Virginia University Cooperative Extension Service. Less than a fifth of the State's landowners have attended this type of demonstration or meeting. 


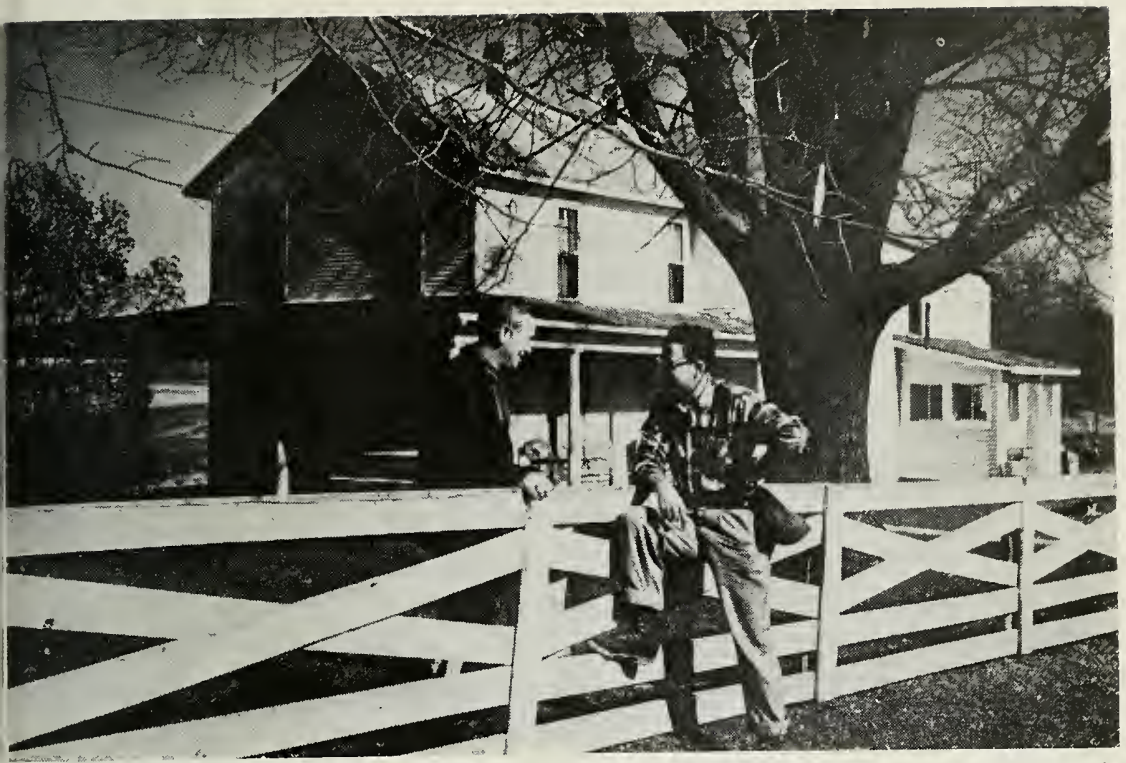

Only 43 per cent of the forest landowners are aware of forestry services available through public agencies.

Respondents were also questioned to learn if they had secured technical forestry information from sources other than professional foresters. About half reported that they had been exposed to some form of forestry information through newspapers and magazines, although 1 in every 2 of these individuals said that they could remember obtaining no more than two items of such information, at best, from these particular sources. One-fourth of the owners said that some forestry information had been received through radio and television programs, one-fifth cited forestry demonstrations and meetings as an information source, and 1 in 10 mentioned technical forestry bulletins.

\section{CONCLUSIONS}

This study was designed to learn more about woodland owners in West Virginia-who they are, how they might best be grouped or classified, their purposes for owning land, their goals regarding the woodland portion of their holdings, and why they feel and act as they do in relation to their woodlands. This implies an essentially descriptive type of analysis and, as a result, most conclusions that might be drawn are relatively self-evident in the discussion of findings. However, one finding is particularly significant because of its implications concerning at least two elements of the present and future timber situation in West Virginia.

"Total not 100 per cent because more than one source could be reported by a respondent. 
Most of the private, non-industrial woodland owners in West Virginia, who in the aggregate control two-thirds of the State's total commercial forest area, seemingly have little interest in the commercial aspects of their forest land. If this is true, two important questions arise: (1) how much of IVest Virginia's rather substantial sawtimber volume is actually available for use by the State's wood-using industry, and (2) what does the lack of a commercial objective signify concerning the prospects of achieving any material, statewide improvement in timber quality and forest land productivity?

Considering the question of economic availability of timber, forest survey data show that "farmer and miscellaneous private" woodland owners hold 23.2 billion board feet of sawtimber-80 per cent of the State's total. ${ }^{10}$ However, the "miscellaneous private" group includes nonwood industry ownerships such as coal companies and land companies who hold an estimated 2,770,000 acres of forest land. ${ }^{11}$ Assuming 2,366 board feet per acre (total sawtimber volume of "farmer and miscellaneous private" owners, divided by the total commercial forest acreage in this owner class), approximately 6.5 billion board feet of sawtimber would be held by the private, non-wood industry owner and 16.7 billion board feet by private, non-industrial owners.

As indicated earlier (Table 3), about half of the private, nonwood industry owners reported a commercial objective for their forest holdings and one-fourth of the private, non-industry owners mentioned this objective. Applying these ratios to the timber volume held by the two owner classes, 7.5 billion board feet of the State's privately owned sawtimber (excluding wood industry holdings) would be economically available for use by the wood-using industry. This amount represents only one-third of the total sawtimber volume reported for this group of owners.

The estimated 7.5 billion feet of available timber is but a rough approximation, based as it is on the assumption that proportions of the number of owners with commercial objectives can be applied to the total timber volume held by all owners in a given owner-class. However, the intent has not been to provide an estimate of economically available sawtimber, as such, but rather to underscore, by way of illustration, the implied significance of one finding of this study.

It appears that the lack of a commercial objective with so large a proportion of the State's private woodland owners necessarily rules out monetary gain as a principal motivator to any widespread adoption of more conservative forest management practices. Thus, whatever future

${ }^{1 n}$ Forest Service, U.S.D.A. The Timber Resources of West Virginia, p. 43.

${ }^{11}$ Grafton, E. A. Forest Land Ownership in West Virginia: Its Characteristics, Patterns, and Trends (M.S. Thesis), West Virginia University, 1963. 
;teps are taken to improve the timber quality-forest productivity prob$\mathrm{em}$, it seems reasonable to expect that prospects of any material success will depend upon the degree to which such efforts recognize that all andowners are not necessarily "economic men," at least in their viewsoints regarding their forest holdings. For example, reduction of woodand grazing might better be accomplished by stressing the impact of grazing on wildlife habitat and the attendant effect on quantity and variety of wildlife. And in this era of water problems, it might well be idvantageous to emphasize the effects of grazing on the quantity and quality of water yield. Similarly, timber stand improvement might be "sold" to more woodland owners if they were approached on the basis of the contribution of such work to recreational use of woodland, to wildlife habitat, and to water yield.

The foregoing examples are not intended as answers, but rather as suggestive of some approaches that might be taken. Actually, foresters have long known the technical practices necessary for improving timber quality and forest land productivity. What has been less clearly understood is how to get these practices into effect.

The findings serve to raise some important questions about the validity of long-held assumptions of many individuals connected in one way or another with forest resource management. However, these findings are not peculiar to West Virginia. A study of 23 townships in the New England states reported that about one-fourth of the 706 forest owners contacted considered timber production as a primary purpose of ownership. ${ }^{12}$ An Idaho study showed that only 18 per cent of the 1,842 woodland owners surveyed viewed forest production as an ownership objective..$^{13}$ A recent study in Michigan indicates that 19 per cent of the 634 woodland owners interviewed have commercial woodland objectives. $^{14}$ An east Texas study showed that 16 per cent of the woodland owners in that region report timber growing as a management objective. ${ }^{15}$ In New York State, 19 per cent of 959 woodland owners surveyed listed a commercial objective relative to their woodland holdings."

Perhaps the principal shortcoming in a study of this type is that the findings are pertinent largely to the time the study was made. People's goals or aims change and it is extremely difficult, if not impossible, to predict with any reasonable certainty the future nature and degree of

${ }_{12}$ Barraclough, S. L. Forest Land Ownership in New England, Ph.D. thesis, Harvard Uni-

versity, Cambridge, Mass., 1949, 269 pp.
is Frazier, George D. Small Non-industrial Forest Owners in Northern Idaho, Bull. 317, Idaho Agr. Exp. Sta., Moscow, Idaho, 1960, p. 14.

In Forest Owners and Timber Management in Michigan, Sta. Research Paper LS-9, Forest Service, St. Paul, Minn., 1964, p. 13.

15Miller, Robert L., and John H. Southern. Management Intent of Small Timberland Owners East Texas, MP-439, Texas Agr. Exp. Sta., College Station, Texas, 1960, p. 5.

1"Christensen, W. W. Methodology for Incestigating Forest Owner's Management Objective, p. 153. 
such changes. Although no reason exists to expect a sudden shift in the current pattern of owners' woodland objectives, it does seem reasonable to assume that change will eventually occur. And if the direction of such change is to be ascertained, it would appear necessary to conduct another study, similar to the present one, at some future date-possibly 10 years hence. 
